\title{
Democracy, Gender Equality, and Customary Law: Constitutionalizing Internal Cultural Disruption
}

Susan H. Williams

Indiana University Maurer School of Law, shwillia@indiana.edu

Follow this and additional works at: https://www.repository.law.indiana.edu/ijgls

Part of the Constitutional Law Commons, International Law Commons, and the Sexuality and the Law Commons

\section{Recommended Citation}

Williams, Susan H. (2011) "Democracy, Gender Equality, and Customary Law: Constitutionalizing Internal Cultural Disruption," Indiana Journal of Global Legal Studies: Vol. 18 : Iss. 1 , Article 4.

Available at: https://www.repository.law.indiana.edu/ijgls/vol18/iss1/4

This Symposium is brought to you for free and open access by the Law School Journals at Digital Repository @ Maurer Law. It has been accepted for inclusion in Indiana Journal of Global Legal Studies by an authorized editor of Digital Repository @ Maurer Law. For more information, please contact rvaughan@indiana.edu.

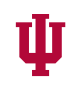

JEROME HALL LAW LIBRARY

INDIANA UNIVERSITY

Maurer School of Law
Bloomington 


\title{
Democracy, Gender Equality, and Customary Law: Constitutionalizing Internal Cultural Disruption
}

\author{
SUSAN H. WILLIAMS ${ }^{*}$
}

\begin{abstract}
Customary law often includes gender discriminatory rules that violate women's rights under constitutional equality guarantees. Dialogic democracy theory offers valuable tools that can help a legal system both to protect customary law and to protect the equality of its women citizens. By focusing on the need for challenge and on the dialogue within the cultural community, the legal system can create incentives and conditions to support the capacity of women to shape the customary law of their own communities. This approach is necessary because legal rights for women, when imposed by the larger society, often result in backlash within minority communities. In the long run, the structural inequality of women cannot be addressed by legal rights alone, but must be addressed by programs that seek to give women the power within their communities to achieve their own equality.
\end{abstract}

\section{INTRODUCTION}

Customary legal systems in many countries pose a serious threat to women's equality rights by legitimizing and enforcing gender discriminatory rules with respect to marriage, divorce, property, and a host of other issues. But freedom to practice one's culture and religion is also a fundamental human right. Is it possible, then, for a country to both respect and make space for the customary legal systems of its various populations and, at the same time, protect the equality rights of

* Walter W. Foskett Professor of Law and Director, Center for Constitutional Democracy, Indiana University Maurer School of Law. I would like to thank Susan Tanner, Huong Thi Nguyen, and Christina Clark for their research assistance on various stages of this project. Parts I, II, and III of this article closely track the arguments I have made in Democratic Theory, Feminist Theory and Constitutionalism: The Challenge of Multiculturalism, in Feminist Constitutionalism: Global Perspectives (Beverly Baines, Daphne Barak-Erez, \& Tsvi Kahane eds., Cambridge U. Press. forthcoming 2011).

Indiana Journal of Global Legal Studies Vol. 18 \#1 (Winter 2011)

(C) Indiana University Maurer School of Law 
its women citizens? Or must the nation simply choose between these two projects, necessarily sacrificing one to the other? In this paper, I argue that greater attention to the internal dialogue of the cultural community provides resources that open up new possibilities for accommodating both sides of this dilemma.

Since Muna Ndulo has provided a detailed description of the types of problems that arise regarding gender equality in customary law systems in his excellent paper in this symposium, I will not repeat that description. ${ }^{1}$ In many cases, the legal system gets involved when a cultural community seeks recognition or accommodation for a practice that would otherwise violate the equality norms of their country's constitution. The literature on multiculturalism has responded to this conflict primarily by choosing one side or the other in the dilemma: some theorists would sacrifice equality to protect culture while others would sacrifice culture to protect equality.

In Part I of this paper, I explain why I believe both those responses are unsatisfactory. I then turn, in Part II, to developing the theoretical tools necessary to build an alternative: a constructivist view of culture and a dialogic model focused on the need for challenge as part of the dialogue. I argue that we must use these tools to focus on the dialogue within the cultural community itself. If a community wants legal protection for cultural practices that treat women unequally, it must show that those practices are subject to a community dialogue in which women have a meaningful opportunity to challenge and reinterpret them. In Part III, I develop a framework for addressing these problems. Finally, in Part IV, I offer some thoughts about how this framework would apply to the issue of customary law in Liberia.

The conclusion I draw is that a rights-based approach, while necessary, is not sufficient to deal with problems caused by the structural distribution of power. Rather, we must look for ways to redress the underlying power imbalances as well. And in this search, legal mechanisms that create resources and opportunities for women to shape the customary law of their own communities will be far more effective than rights provisions that depend upon enforcement by the state. In other words, in constitutional design terms, rights are not a sufficient solution to structural problems.

1. See Muna Ndulo, African Customary Law, Customs, and Women's Rights, 18 IND. J. Global LEGAL STUD. 87 (2010) (discussing the problems that arise regarding gender equality in customary law systems). 


\section{THE CONFLICT AND THE CURRENT LITERATURE}

As Ayelet Shachar describes in her book, Multicultural Jurisdictions, ${ }^{2}$ the literature has tended to resolve the problem of discriminatory cultural practices by going to one extreme or the other: some theorists would allow a cultural group to restrict or discriminate against its own members with very few limits beyond a guarantee that those members have freedom to exit, ${ }^{3}$ while other theorists would refuse to allow any discrimination or restrictions that violate the rules applicable within the majority legal culture. ${ }^{4}$ Both of these extreme responses are highly problematic. ${ }^{5}$

The problem with relying on exit as the basis for allowing mistreatment of women is twofold. First, in order to function as a justification, exit cannot simply be a theoretical possibility; it must be a practical possibility. But economic, social, and emotional realities often make exit a less than meaningful option for vulnerable people, including many women. ${ }^{6}$ Second, even if exit is truly possible, this approach forces a woman faced with discriminatory cultural practices to choose between her rights as a citizen and her culture: since the only way to vindicate the former is to exit from the latter, she cannot have both. ${ }^{7}$

2. Ayelet Shachar, Multicultural JURisdictions: CULtural Differences aND WOMEN'S RIGHTS 63-71 (2001).

3. See, e.g., Chandran Kukathas, Are There Any Cultural Rights?, in THE RIGHTS of MINORITY CULTURES 228, 247-48 (Will Kymlicka ed., 1995).

4. See, e.g., Susan Moller OKIn, Is Multiculturalism Bad for Women? 9-24 (1999); see generally BRIAN BARRY, CULTURE \& EqUALITY: AN EGALITARIAN CRITTQUE OF MULTICULTURALISM (2002).

5. For an argument that the international conventions in the area have made a similar dichotomous choice, see Johanna Bond, Gender, Discourse, and Customary Law in Africa, 83 S. CAL. L. REV. 509, 511-12 (2010) (arguing that the Convention on the Elimination of All Forms of Discrimination against Women dismisses culture, failing to see its importance to women, and the African Charter dismisses equality, protecting culture even at the cost of gender equality).

6. See Sarah Song, JUSTICE, GeNder, AND the Politics of MUlticulturalism 16162 (2007) (describing psychological and practical conditions for meaningful exit); Sawitri Saharso, Female Autonomy and Cultural Imperative: Two Hearts Beating Together, in CITIZENSHIP IN DivERSE SOCIETIES 224, 229-31 (Will Kymlicka \& Wayne Norman eds., 2000) (describing how culture can limit the capacity for autonomy); see generally Oonagh Reitman, On Exit, in MINORITIES WITHIN MINORITIES: EQUALITY, RIGHTS, AND DIVERSITY 189, 192-204 (Avigail Eisenberg \& Jeffrey Spinner-Halev eds., 2005) (arguing that exit cannot play the protective and transformative roles assigned to it).

7. See SHACHAR, supra note 2, at 70-71. Gurpreet Mahajan has also pointed out that exit is not a very meaningful option if the larger society continues to regard you (perhaps because of the color of your skin or the ethnicity of your name) as a member of the minority community even after you leave. Gurpreet Mahajan, Can Intra-group Equality Co-exist with Cultural Diversity? Re-examining Multicultural Frameworks of Accommodation, in MINORITIES WITHIN MINORITIES, supra note 6, at 90, 102. 
The alternative approach, by enforcing equality norms on all cultural practices, leaves no room for the existence of communities that dissent from the legal culture of equality. Here, our response might differ depending on whether the dissenting cultural group represents a majority or a minority. If the dissenting group is a minority, then the issue here is simply whether or not one is willing to abandon cultural and religious rights for minority groups. One might value the protection of minority cultures for a variety of different reasons: the contribution of cultural communities to individual autonomy, ${ }^{8}$ the role of such communities in providing the goods of belonging, ${ }^{9}$ or the value of dissenters to the democratic dialogue in the larger society. ${ }^{10} \mathrm{But}$, whatever the reason, much of the value will be lost if minority cultures are squeezed out by the majority in this way. ${ }^{11}$ In other words, this approach is really only possible for those who do not regard the inclusion of minority cultures as an important priority of justice.

If the problematic culture is a majority culture, on the other hand, then the question becomes whether legal sources of human rights-such as a constitution or international convention-should be understood to prevent the majority from expressing its culture through discriminatory customary legal rules. Whatever one thinks of the theoretical arguments in this context, there is a powerful pragmatic problem with simply choosing equality rights over culture in this situation: it often does not work very well.

First, it does not work very well because legal systems that include both a commitment to gender equality and a commitment to a particular customary or religious culture have not proven to be particularly good at choosing gender equality when the two come into conflict. We may believe that they should make this choice, but there is little practical assurance that the people with power in such systems-judges, government officials, and others who will be interpreting and applying the laws-will actually do so. After all, these people are very likely to share the majority culture that is in conflict with the equality norm, and

8. See generally WLL KYMLICKA, MULTICULTURAL CITIZENSHIP: A LIBERAL THEORY OF MINORITY RIGHTS (1995).

9. See generally JAMES TULly, STRANGe MULTIPLICITY: CONSTITUTIONALISM IN AN Age of Diversity (1995); Charles Taylor, SOURCes of THE SELF: THE MAKING of THE MODERN IDENTITY (1992).

10. See Monique Deveaux, Cultural Pluralism and Dilemmas of Justice 34 (2000).

11. Cf. Jeff Spinner-Halev, Autonomy, Association, and Pluralism, in MINORITIES WITHIN MINORITIES, supra note 6, at 157, 165 ("If all private groups are remade in the image of the liberal state, then everyone's choices are reduced.") 
so they are likely to look for a way to compromise the two values rather than simply choosing equality over culture. ${ }^{12}$

Second, even when these actors do choose to enforce gender equality norms at the cost of cultural practices, such enforcement often does women very little good. In many cases around the world, the result of such efforts to impose greater equality has often been that the women involved are worse off afterward. Sometimes this is because the women are put under tremendous pressure by their communities to renounce the benefits that the legal system is trying to extend to them, as in the Shah Bano case in India. ${ }^{13}$ Sometimes this is because the community forces the girls or women out of the public institutions in which the more equal practice is enforced, as in the case of Turkish university students who, either through their own choices or due to family pressure, left the universities that would not allow them to wear headscarves. ${ }^{14}$ If the goal is to help the actual, individual women whose welfare is at stake in such cases, it is not at all clear that an intransigent position by the legal system refusing to accommodate the cultural community does in fact help these women.

Finally, this simple "either/or" approach to culture and equality fails to recognize women's interests in being active members in and shapers of their culture. Women are not merely the victims of culture: they "act with agency, engaging with and reformulating cultural policy .... as they work to eliminate discrimination within their cultural communities." 15 Constructing the problem as culture versus equality, where the legal system simply has to choose a side, casts women as the passive victims of culture rather than as its active creators. In so doing,

12. In many ways, South Africa may be the strongest case for the idea that a commitment to gender equality can function as a trump over cultural rights that also have constitutional status. But even in South Africa, where the Constitutional Court has exercised tremendous initiative and where the constitutional commitment to gender equality is stronger than in most other countries, the progress is probably best described as two steps forward and one step back. See, e.g., Sara Jagwanth \& Christina Murray, No Nation Can Be Free When One Half of It Is Enslaved, in THE GENDER OF CONSTITUTIONAL JURISPRUDENCE 230 (Beverly Baines \& Ruth Rubio-Marin eds., 2005); Monique Deveaux, Liberal Constitutions and Traditional Cultures: The South African Customary Law Debate, 7 CITIZENSHIP STUD. 161 (2003) [hereinafter Deveaux, Liberal Constitutions]. In Liberia, where the courts have much less experience with resisting other branches of government and where the commitment to gender equality does not have as strong a constitutional foundation, this strategy is likely to be significantly less successful.

13. Mohammad Ahmed Khan v. Shah Bano Begum, (1985) 2 S.C.C. 556 (India). For a discussion of the Shah Bano case, see Martha Nussbaum, India, Sex Equality, and Constitutional Law, in THE GENDER OF CONSTITUTIONAL JURISPRUDENCE, supra note 12, at $174,190-91$.

14. See SoNG, supra note 6 , at 174-75.

15. Bond, supra note 5 , at 511 . 
it both falsifies the situation in which many women find themselves-a situation in which they feel committed to both their culture and their equality - and obscures possibilities for resolving these tensions in more productive ways.

\section{A FEMINIST APPROACH}

So, how can a constitutional system respect and accommodate customary law while also protecting and respecting the equality rights of women? A number of feminist theorists have turned to a more complex understanding of culture and to models of democratic dialogue to provide a method for promoting both of these goals.

These theorists have insisted on a constructionist approach to culture in which cultural communities are seen neither as isolated nor as monolithic: cultures have always interacted with each other and shaped one another and they have also always been internally heterogeneous. ${ }^{16}$ Sarah Song describes four elements of this constructivist model: (1) "cultures are the product of specific and complex historical processes, not primordial entities"; (2) "cultures are internally contested, negotiated, and reimagined by members, who are sometimes motivated by their interactions with outsiders"; (3) "cultures are not isolated but rather overlapping and interactive"; and (4) "cultures are loose-jointed. . . . the loss or change of one strand does not necessarily bring down the entire culture."17

For the purposes of this paper, the most important aspect of this model is the internally contested nature of cultures. We must pay attention to the power dynamics within a group and the ways in which the cultural community's interaction with the legal system affects the status, power, and resources of subgroups within the cultural community. Certain forms of legal accommodation of culture have a systematic effect of supporting traditional authority figures in the community, and their views of the culture, at the expense of the power and perspectives of more marginalized groups, including women. ${ }^{18}$ For example, reserving seats in the legislature for particular cultural groups or incorporating traditional cultural norms into the state legal system both tend to strengthen traditional leaders-who are overwhelmingly

16. See Iris Marion Young, Together in Difference: Transforming the Logic of Group Political Conflict, in THE RIGHTS OF MINORITY CULTURES, supra note 3, at 155, 159-61.

17. SONG, supra note 6 , at 32 .

18. See ANNe Phillips, Multiculturalism Without Culture 163 (2007) for a critique of consociationalism for increasing the power of elites. Phillips also criticizes the incorporation of traditional legal systems as making one interpretation of norms authoritative. Id. at 169 . 
male-as against more marginal or progressive elements in the community. There is no neutral position for the state here: action and inaction both have consequences for the distribution of power and status inside the cultural community.

Many of the feminist theorists also look to democratic models of dialogue as a mechanism for dealing with these problems. Anne Phillips suggests that dialogue is the most promising approach because it recognizes both difference and the possibility of intercultural understanding and can encourage internal transformation of the community. ${ }^{19}$ Similarly, Seyla Benhabib uses a deliberative model of democracy to describe the interaction between majority and minority cultural groups and how it can give rise to workable solutions to some of these issues. ${ }^{20}$ Iris Marion Young's well-known defense of certain forms of group rights is based on a deliberative model of democracy. ${ }^{21}$ Monique Deveaux develops "a more robust conception of democracy," 22 which is a deliberative model with some important modifications. ${ }^{23}$ Sarah Song asserts that democratic deliberation must have a central role in determining which accommodations justice requires in multicultural societies. ${ }^{24}$ And Judith Squires endorses a vision of diversity politics focused on contextual impartiality and democratic deliberation as the basis for bringing feminism and multiculturalism together. ${ }^{25}$ While there are many real disagreements among these theorists about the specific form and implementation of a deliberative democratic approach, they all see this model as offering the best foundation for dealing with multicultural issues.

I agree with these theorists that a democratic dialogue between the many groups in a pluralist society is an important part of the process for resolving the difficult cases concerning cultural accommodation. The particular observation I want to offer here is that a dialogic, democratic approach to the problem of cultural practices that violate equality norms requires additional attention to the dynamics within the cultural

19. Id. at 161. She cautions, however, that the dialogue must be structured carefully or it will tend to increase the power of authority structures within the community, for example, by endorsing traditional leaders as spokespersons in the dialogue. Id. at 161-62.

20. SEyla Benhabib, The ClaIms of Culture: EQuality aND Diversity IN THE GLOBAL ERA 105-46 (2002).

21. See generally IRIS MARION YOUNG, INCLUSION AND DEMOCRACY (2000).

22. DEVEAUX, supra note 10, at 3-5 (rejecting a requirement of consensus and insisting that deliberative democracy is not neutral but based on specific norms, which must be made explicit and justified).

23. Id. at 140-41.

24. See SoNG, supra note 6 at 10 .

25. Judith Squires, Culture, Equality and Diversity, in MULTICULTURALISM REConsidered 114, 120 (Paul Kelly ed., 2002). 
community and not only to dialogue between the community and the larger society. While all of the theorists I am describing recognize this issue, none of them has focused her attention on it. ${ }^{26}$ Their focus is on the nature of the dialogue within the larger society: the conditions under which that dialogue can take place, the role of the minority community in that conversation, and the ways in which the dialogue might contribute to the solution of hard cases.

Moreover, there is an element of the dialogic model that needs to be made much clearer and should be the focus of attention in the application of this model to the internal dialogue of a cultural community. That element is challenge. A dialogic model of democracy requires attention to the role of disruption and challenge in preventing the reintroduction of domination and oppression. Such disruption and challenge is crucial and cannot simply be assumed-incentives and support for it must be built into the democratic structure. ${ }^{27}$ Thus, one important aim of accommodation in multicultural contexts should be to provide support for such challenge by women within the community's dialogue. Indeed, I believe that this approach is necessary, although not

26. Monique Deveaux has given the most attention to this issue in two writings. First, in one essay, she offers a clearer statement of her conviction that democratic processes must apply within the cultural minority community, and not just between that community and the larger society. Monique Deveaux, A Deliberative Approach to Conflicts of Culture, in MiNORITIES WITHIN MiNoRITIES, supra note 6 , at 340,343 [hereinafter Deveaux, $A$ Deliberative Approach]. She also offers some guidelines for the dialogue that are useful for internal as well as external purposes. $I d$. at 350-51 (including non-domination, political equality, and revisability). Nonetheless, the example she uses to illustrate the process is still an external conversation-between community members, outside experts, and representatives of the larger society-rather than the ongoing, internal process of cultural construction, interpretation, and implementation. Id. at 356-61 (describing the process of public consultation preceding the passage of the South African Customary Marriages Act of 1998). In her article, Liberal Constitutions and Traditional Cultures, she again suggests the need for a dialogue within the cultural community. Deveaux, Liberal Constitutions, supra note 12 . Here she raises the important point that such struggles should be seen as fundamentally political (i.e., about interests and power) rather than fundamentally normative (i.e., about conflicts in values). Id. at 162 . She suggests some guidelines to help frame such dialogue: starting from norms that enjoy wide acceptance, looking for compromise rather than for consensus on shared norms, focusing on concrete interests, and preventing power abuses. Id. at 173-76. But, again, she is envisioning a process set up by (and possibly mediated by) the state rather than a process internal to community. Id. In addition, she does not consider the use of accommodation as itself a mechanism for encouraging internal dialogue. This essay is intended to add those missing elements.

27. For a more detailed version of the argument for including the element of challenge in a model of dialogic democracy, see Susan H. Williams, Equality, Representation, and Challenge to Hierarchy: Justifying Electoral Quotas for Women, in CoNSTITUTING EQUALITY: GENDER EQUALITY AND COMPARATIVE CONSTITUTIONAL LAW 53 (Susan H. Williams ed., 2009). In that chapter, I apply this framework to the issue of electoral gender quotas for women. 
sufficient, to any long-term solution to the difficulties posed by claims for cultural accommodation that are in tension with a constitutional commitment to equality.

In a model of dialogue based on democratic values, participants engage in a collective process of "free and reasoned deliberation among individuals considered as moral and political equals." 28 But a number of theorists, including Bonnie Honig, Jane Mansbridge, and Nancy Fraser, have recognized that there is a danger in a dialogic model that does not reckon seriously enough with the ineradicability of power. ${ }^{29}$ Difference is inevitable, and there is constant pressure for people with power to use existing differences to generate or reinforce hierarchy, thereby undermining the necessary equality of the dialogue. The risk of a deliberative model of democracy is that we will too quickly assume that our deliberative processes are free of coercion (when they are not), or that our dialogue has resulted in a good that is common (when it is not). The ideal of a politics free of power and domination is an ideal worth embracing, but if we think that any actual politics has achieved that ideal, then we are allowing ourselves to be led astray by the dream.

This problem is particularly acute in the context $I$ am addressing here: the situation of women attempting to participate in and reshape cultural institutions that include gender discriminatory and sexist elements. As Johanna Bond points out:

Traditional leaders are primarily male elites who enjoy significant social and political power. . . Women who challenge customary norms as violative of gender equality rights often enjoy considerably less political power within their communities. Furthermore, the act of openly challenging custom and tradition exposes those women to increased stigma and ridicule within the community. ${ }^{30}$

Simply allowing for a dialogue will be insufficient because of the high likelihood that power will distort the dialogue through a variety of

28. Seyla Benhabib, Toward a Deliberative Model of Democratic Legitimacy, in DEMOCRACY AND DIFFERENCE: CONTESTING THE BOUNDARIES OF THE POLITICAL 67, 68 (Seyla Benhabib ed., 1996) [collection hereinafter DEMOCRACY AND DIFFERENCE].

29. See Bonnie Honig, Difference, Dilemmas, and the Politics of Home, in DEMOCRACY AND DIFFERENCE, supra note 28, at 257-77; Jane Mansbridge, Using Power/Fighting Power: The Polity, in DEMOCRACY AND DIFFERENCE, supra note 28, at 46-66; Nancy Fraser, Rethinking the Public Sphere: A Contribution to the Critique of Actually Existing Democracy, in Habermas AND THE Public Sphere 109, 123 (Craig Calhoun ed., 1992).

30. Bond, supra note 5 , at 562 . 
mechanisms. For example, women may feel uncomfortable speaking up in the public context because of gender role expectations. ${ }^{31} \mathrm{Or}$ the dialogue may be conducted within frames of reference that reinforce existing power hierarchies and are largely unnoticed because they coincide with existing social realities. ${ }^{32}$ In short, dialogue alone, without direct and sustained attention to creating incentives and opportunities for challenge, will be insufficient. ${ }^{33}$

As a result, we need mechanisms for ensuring that the people most likely to be marginalized in the dialogue are included and heard. We need to build into the model of dialogue attention to the risks of exclusion and hierarchy as well as incentives and opportunities to challenge them. One way to do this is to focus on these issues in the context of claims for cultural accommodation. In this context, accommodation is more warranted as the cultural group demonstrates more willingness to carry on an internal dialogue in which such challenge is possible. Taking this approach is not the same as asking whether the cultural practices at issue in the accommodation claim are consistent with liberal individual rights. Here we are focused not on the specific practices at issue in the accommodation, but on the methods through which such practices are created, interpreted, and implemented. If those methods-and the background conditions under which they operate-allow for meaningful challenge, then the legal system should offer a greater degree of accommodation to the cultural practice, even if the practice includes some features that might otherwise be seen as inconsistent with the constitutional commitment to equality.

31. See Heike Becker, 'New Things After Independence': Gender and Traditional Authorities in Postcolonial Namibia, 32 J. S. AFR. STUD. 29, 42-43 (2006) (explaining that both men and women describe women as too "shy" to participate in public meetings).

32. See Iris Marion Young, Activist Challenges to Deliberative Democracy, 29 POL. THEORY 670, 686 (2001).

33. Because of these concerns about power, Johanna Bond argues that the dialogic model should be limited to "localized modes of [norm] implementation" and that the norms themselves should be taken from the Protocol to the African Charter on the Rights of Women in Africa. Bond, supra note 5, at 513, 510-16. I do not believe that this is an adequate solution for two reasons. First, the two tasks of establishing norms and providing localized modes of implementing them can not be as neatly separated as Bond suggests. I am afraid that the power to implement or apply is essentially the power to define the norms themselves. As a result, I am not as optimistic as Bond that this substantive limit will have the effect of restricting the degree of harm to women. Second, as Bond herself recognizes, "limiting the scope of deliberation will not eliminate the power disparities that necessitate the approach in the first place." Id. at 567. I believe we are better served by a dialogic model that takes on the issue of structural inequality directly, rather than merely attempting to contain the reach of such inequalities by limiting the scope of the deliberation. 
Openness to challenge is not an all-or-nothing matter. There is a minimum level of dialogic openness that is required of all communities, in the form of bans on extreme coercion, such as imprisonment. ${ }^{34}$ But, beyond this minimum, the legal system should continue to encourage the development of more inclusive and open dialogic conditions within the community. Assuring that the internal dialogue within a community includes challenge to inequality and domination requires that the vulnerable members of that community have a meaningful voice in the dialogue. Many writers have outlined the theoretical requirements for such a dialogue, but these are not particularly useful in a context in which the inequalities are deep and structural and there is no forum in which they can simply be eliminated. ${ }^{35}$ The goal is not to create a list of preconditions for an equal dialogue, since such conditions will surely be unmet in any realistic setting in which these conversations might take place. Instead, the goal is to identify practical mechanisms for creating resources, opportunities, and incentives that will move the dialogic participants toward ever greater inclusivity and openness to challenge.

\section{APPLICATION TO CUSTOMARY LAW}

There are three different mechanisms the legal system could use to encourage and support internal dissent and challenge. First, the legal system could increase the capacity for challenge by giving women within the cultural community recognition and social capital. Second, the legal

34. It is interesting to note the high level of consensus among the feminist theorists I am describing on the identification of a category of accommodation claims that all of them would reject. These are claims where the harm visited on the vulnerable member by cultural practices is severe, generally physical, and in clear violation of the generally applicable criminal laws. For example, all of these theorists agree that the "cultural defense" should not excuse a man who kills his wife or other female family member in a so-called "honor" killing. If such a defense were accepted, that would effectively function as an exemption for members of that cultural group from the usual criminal laws on murder. While the writers I describe offer different views about why these defenses should not have this result, and also differ on what other relevance (if any) such cultural information might have in a criminal case, they all agree that no exemption is appropriate here. Perhaps one might say that these cases form an "overlapping consensus" among feminists who are sympathetic to the claims of cultural communities about where the limits of accommodation lie.

35. For example, Monique Deveaux proposes that one of the requirements of the dialogue is political equality between participants: the opportunity to participate in and influence the outcome of the dialogue cannot be affected by other sorts of inequalities, such as wealth, power, and gender. Deveaux, $A$ Deliberative Approach, supra note 26, at 350-51. While I believe this is a wonderful ideal, I am afraid that it is likely to be unattainable in most communities for the forseeable future. As a result, a more limited and more specific set of concerns would be more useful as guidelines for resolving these issues. The requirements discussed in text are intended as a first cut at such specific guidelines for an adequate level of guaranteed participation. 
system could increase women's capacity for challenge by redistributing practical resources to them, such as economic power and education. Third, the legal system could offer the community accommodation of its unequal cultural practices on the condition that it adopts internal dialogic processes that provide opportunities to challenge dominant practices. The first two mechanisms are aimed at ensuring that women have the resources and capacity for making challenges; the third mechanism is aimed at ensuring that they have the opportunity to use that capacity.

In implementing all three of these methods, however, it is important for the state to enlist the cooperation of traditional community leaders as much as possible. Otherwise, the state's support and encouragement for the women will simply lead the rest of their community to demonize them as a tool of the oppressive outside culture. There is probably no way to avoid this completely, but the more that the interests and status of the traditional leaders can be tied to the recognition and empowerment of women, the less powerful this negative response will be.

\section{A. Recognition}

The state needs to seek out and support multiple representatives and spokespeople for women within cultural communities, preferably long before any specific claim seeking accommodation is raised. This can often be best achieved in the realm of public debate and discussion, outside of the particular arena of government. For example, mainstream news media should routinely look for representatives of women's groups internal to minority communities for comment on issues concerning that community. Civil society organizations seeking input from representatives of a particular community should do the same. And government also should seek out and invite participation by women's groups internal to cultural communities as part of any consultation process.

It is difficult to enlist the traditional community leaders in this process because they are very likely to endorse women's representatives who are less critical of traditional authority, which would, of course, undermine the purpose of supporting challenge. So, it is probably not useful to attempt to involve these traditional leaders in the process of identifying women's representatives. It is, however, extremely useful to bring the traditional leaders together with the women's representatives in conversations about the community's needs and concerns. If these conversations take place in contexts in which both sets of leaders are representing the community's interests to the larger society (i.e., in a 
context not focused on an accommodation opposed by the women), then there is the possibility for a positive dynamic. In many cases, they are likely to agree on at least some of the goals of the community, and the opportunity to discover such common ground in the context of presenting the community's desires to the larger society can help to build trust and cooperation between these leaders. ${ }^{36}$

\section{B. Redistribution}

The state needs to offer practical support to women that will increase their power to speak up and challenge the hierarchies in their own communities. Such support might take the form of opportunities for education, economic development, and protection from domestic and other forms of intracommunity violence. As many observers have noted, the reason that exit is an insufficient solution is that women often experience very substantial barriers to exit, in the form of economic, educational, and social limitations that dramatically raise the cost of leaving. ${ }^{37}$ At a minimum, the state should provide the sort of support that reduces the impact of such limits.

The state should also try to enlist the support of traditional community leaders for programs that provide resources to the women of the community. The goal is for these leaders to see such programs as benefitting the community as a whole. One way to encourage that view would be to offer the benefits (e.g., education and economic development support) to both men and women in the community, but to increase the amount of support based on the percentage of recipients who are women. For example, the state might offer scholarship aid to members of a disadvantaged group, and the total amount available for scholarships might increase as the percentage of women participating in the scholarship program increases. Or the state might enlist women by using their traditional roles (e.g., as mothers) to give them resources and training (e.g., on organizing and teaching) that will increase their capacity more generally. Another method is for the government to provide public recognition for the traditional leaders in communities with high rates of female participation in programs like these two examples. The goal is to craft mechanisms that create incentives for the community leaders to encourage women to take advantage of these opportunities, rather than the reverse.

36. See id. at 356-58 (describing how women, along with traditional leaders, supported some customary practices in the discussion over the South African Customary Marriages Act.)

37. See supra note 6. 


\section{Accommodation Tied to Dialogue}

Most importantly, the state should tie accommodation of cultural practices to the development and support of internal dialogic practices that are inclusive and open to challenge. If the state specified the precise dialogic practices required, it would be very likely to create a backlash of what Ayelet Shachar has called "reactive culturalism": where the minority community hardens its own cultural barriers to equality in response to pressure by the majority to be more egalitarian. ${ }^{38}$ In order to minimize this dynamic, the legal system should set out the general goals of the dialogic practice and then leave it to the cultural community to come up with the precise mechanisms for promoting those goals. When a community requests an accommodation, the community would bear the burden of showing that its internal dialogue includes the necessary openness to challenge in order to justify that accommodation. The community must demonstrate that it has strong internal mechanisms to allow such challenges to be made, heard, and considered, so that its cultural practices have the capacity to adapt over time to the needs, desires, and values of its members.

The general guidelines or goals for such an inclusive and open internal dialogue should include at least three parts. First, the process must allow information about alternatives to the current practice. There must be opportunities for people to hear about how other communities handle similar issues and about alternative interpretations of their community's traditions and practices. Moreover, the traditional leaders cannot monopolize the presentation of this information; people who actually support these alternative practices must be allowed to speak in favor of them. I realize that some communities would prefer that their members not be aware of alternative practices or interpretations, but such ignorance is inconsistent with any robust model of dialogue, particularly once we see challenge as a central part of dialogue. If challengers are limited to making arguments against the current orthodoxy, without being able to present alternatives to it, they will be seriously disadvantaged.

Second, the dialogue must include broad participation by dissenters. Those who wish to challenge the traditional practice, or the traditional leaders' interpretation of that practice, must be given meaningful opportunities to do so. A meaningful opportunity would generally mean at least that (1) different groups within the community must be allowed to speak for themselves and cannot be forced to be represented by spokespersons not of their choosing, and (2) the dissenters must be

38. SHACHAR, supra note 2, at 35-37. 
heard by a broader audience than just the traditional leaders of the community. The point here is that the dissenters must be given the chance to affect the culture of their community. ${ }^{39}$

Third, the ultimate decision of the community on the practice at issue must demonstrate some recognition of and concern for the views of dissenters. This does not mean that the community must necessarily adopt the views of the dissenters, but it cannot completely ignore them either. It must show that it has considered them and attempted to accommodate them to some extent. One aspect of this concern is captured by Monique Deveaux's requirement that the outcomes of such dialogue must be revisable-they must be seen as capable of being reopened and altered in the future. ${ }^{40}$ Revisability is necessary to assure dissenters that their concerns have not been permanently foreclosed, but it may not be sufficient for the purposes of the requirement I am describing. In addition to revisability, the community must demonstrate some understanding of and sympathy for the concerns of dissenters. In other words, the community must demonstrate some of the same willingness to accommodate its own minorities that it is requesting from the legal system for itself. ${ }^{41}$

\section{AN ILLUSTRATION: LIBERIA}

Let me illustrate the application of this approach by taking an example from my work as a constitutional advisor in Liberia. Liberia is a country of approximately three million people in West Africa. It is a multicultural society that includes dozens of tribal groups with different languages, cultures, and religious traditions. Liberia has suffered from a brutal civil war that lasted for most of the period between 1989 and 2003. The war destroyed the infrastructure of the country-including power, water, and road systems-and disrupted social institutions, including the educational and political systems, the clan and village structures, and families. In 2005, Liberia held its first election since the civil war and elected the first woman head of state in Africa, Ellen Johnson-Sirleaf. Liberia has substantial natural resources, including

39. There may be additional procedural requirements that are necessary to allow the voices of vulnerable internal minorities to be heard effectively. For example, if women are afraid to speak up publicly because of the risk of retribution, then there would need to be anonymous mechanisms for participation. The specific conditions necessary for honest participation will vary with the circumstances of different communities of women. So, the suggestions in text, while necessary, may not be sufficient as conditions for assuring adequate dialogue.

40. Deveaux, A Deliberative Approach, supra note 26, at 350-52.

41. See Leslie Green, Internal Minorities and Their Rights, in THE RighTs OF MINORITY CULTURES, supra note 3, at 257. 
rubber, timber, forest crops, and iron, but it faces enormous challenges in every area of life: social, economic, political, educational, and legal.

The Liberian Constitution is largely based on the U.S. Constitution and creates a legal order with many of the features of a liberal state. The Constitution includes a right to gender equality ${ }^{42}$ and also makes a commitment to promote cultures and traditional values that "are compatible with public policy and national progress." 43 This provision is understood to authorize the recognition of customary legal systems, ${ }^{44}$ but the system that has evolved in Liberia is complicated. First, there is the civil or state-run system, in which the official courts apply the statutory law created by the legislature and the common law developed by those courts. The family and personal law applied by the state courts has been reformed in recent years to promote greater gender equality. Second, there is the informal customary law system in which local leaders are asked by those involved to resolve disputes in accordance with local custom. And third, there is a hybrid system, in which tribal chiefs appointed by the President sit as magistrates and apply a combination of statutory codifications of customary laws and actual local customs.

In many places in Africa, colonial occupation has left a complicated legacy for customary legal systems. In some countries, the local chiefs were co-opted by the colonial authorities and came to be seen as collaborators during the movement for independence. As a result, their authority was compromised to varying degrees and needed to be reestablished during the post-independence period. ${ }^{45}$ In addition, in many places, the colonial authorities sought to codify customary law through a process that privileged the interpretations of traditional authorities (mostly male) and that hardened the rules in a way antithetical to a living legal tradition. ${ }^{46}$

Although Liberia never experienced a colonial occupation, it has nonetheless had similar problems. In the absence of a colonial administration, local chiefs have been discredited in a similar way by their dependence on the President. The chiefs are chosen by the President and serve at the President's pleasure. Liberia has a history of

42. Article 11(b) provides that "[a]ll persons, irrespective of . . . sex . . . are entitled to the fundamental rights and freedoms of the individual. ..." The following subsection (c) provides that "[a]ll persons are equal before the law and therefore entitled to the equal protection of the law." Constitution of Republic of Liberia, Jan. 6, 1986, art. 11(b),(c).

43. Id. art. $5(\mathrm{~b})$.

44. In addition, the Constitution mentions customary law directly in article 23(b), where it calls upon the legislature to enact laws to govern "rights of inheritance and descent for spouses of both statutory and customary marriages." Id. art. 23(b).

45. See, e.g., Becker, supra note 31, at 33-34.

46. See Deveaux, Liberal Constitutions, supra note 12, at 164-65. 
excessively powerful, corrupt, and dictatorial presidents. As a result, these chiefs are often seen more as corrupt politicians than as traditional leaders. Liberia has also experienced the same process of codification of customary law as other African nations. In the absence of a colonial power, the resulting legislation is not seen as a tool of an external culture, but it nonetheless suffers from the same flaws of privileging the traditional authorities and freezing the living nature of the law.

Customary law for many of the tribal groups in Liberia includes gender discriminatory practices, including the treatment of adult women as minors, the inability of women to inherit property either from their fathers or their husbands, the tradition of levirate, polygyny, bride price, and female genital cutting. ${ }^{47}$ There is great controversy in Liberia now over which customary rules ought to continue to be enforced and respected and over the interaction between the civil and customary legal systems. The approach developed in this article suggests that one very important consideration should be the ways in which the state-based legal system can empower women within the tribal communities to challenge customary practices that hurt them. Below, I point out three applications of this approach.

First, Liberian women, particularly in rural communities, need much greater support to be able to speak up effectively. One avenue, which has been promoted with energy and determination by the Association of Female Lawyers of Liberia, is education for women about the legal rights and remedies available to them. In addition, the reconstruction of the educational system-with particular attention to school attendance by girls-is a crucial, long-term support for girls and women in their efforts to shape their communities. There are a great number of issues related to breaking down barriers to girls' education, including: eliminating school fees, ensuring girls' safety in and on the way to school, and educating the public about the value of educated girls to the community. 48

Obviously, reconstructing the educational system is a large-scale, long-term reform, and the customary law issues will not be able to wait until this reform has been achieved. But the connection here has an

47. For descriptions of some of these practices among different groups, see, for example, CAROLINE H. BLEDSOE, WOMEN AND MARRIAGE IN KPELLE SOCIETY 82-117 (1980) and GÜNTER SCHRÖDER \& DIETER SEIBEL, ETHNOGRAPHIC SURVEY OF SOUTHEASTERN LIBERIA: THE LIBERIAN KRAN AND THE SAPO 126-40 (1974).

48. Higher educational levels for women correspond to lower levels of fertility and higher levels of child health. See Martha Ainsworth et al., The Impact of Women's Schooling on Fertility and Contraceptive Use: A Study of Fourteen Sub-Saharan African Countries, 10 WORLD BANK ECON. REV. 85-122 (1996). 
important implication for the issue of customary law. The state-based legal system should allow customary law to vary from the civil law rules to a greater extent as this educational reconstruction progresses further. This linkage should help recruit traditional leaders, who want a wider scope for customary law, to support the reconstruction and reform of the educational system and the enrollment of female students.

Second, the hybrid system should be abandoned. In place of presidentially appointed chiefs, the tribal communities should be encouraged to develop decision-making mechanisms that both reflect local custom and incorporate meaningful opportunity for dialogue and challenge. Moreover, these mechanisms should be under much more local control, so that they can vary from one village to another even within a particular tribal group. This decentralization will not only make the system more accessible for people in rural Liberia, but also will allow the development of alternative approaches and interpretations that will open space for challenge to cultural orthodoxies (e.g., "if they do things differently in the next village over, even though they are Krahn, just like us, then maybe we can do things differently here as well"). The government bureaucracy charged with overseeing the customary legal system should keep records about the procedures adopted in different localities and widely disseminate this information so that people in the villages can learn about good ideas that have been tried elsewhere.

Moving back to a more local, flexible, and custom-based system will, of course, create a potential for variations that are harmful to women, but local Liberian cultures include meaningful resources for building more democratic and egalitarian systems. For example, among the Glebo of the southeastern part of Liberia, there is a tradition of female leaders with positions parallel to male leaders: a women's chief, a women's council, and even a role for the wife of the high priest, which includes many of the same duties and ritual prohibitions as her husband's. Moreover, important decisions, such as whether to go to war, could traditionally be vetoed by the women's council and chief. ${ }^{49}$ There is also a tradition of mass action by women to demand attention for issues the male authorities are ignoring. This tradition continues into the current era. One particularly powerful example was a strike organized by the Market Women's Association during the presidency of Samuel Doe in the 1990s. The women refused to return to work until Doe released a group of student activists (whom the women referred to

49. Mary H. Moran, Liberia: The Violence of Democracy 40-42 (2006). For a fascinating account of similar structures in Namibia (including female chiefs and women's participation in traditional community meetings) and their revitalization in certain localities, see Becker, supra note 31 , at 29-48. 
as their children) who had been sentenced to death for their political opposition. ${ }^{50}$

Given these resources, it is inappropriate to assume that traditional mechanisms will automatically or inevitably be unfair to women. The factors that influence the ability of women to make use of these resources are many and varied. They surely include the political and economic pressures at work in any given community, national and international influences, and the agency of individuals and groups at the local level. ${ }^{51}$ Because these factors are complex and vary from one locality to another, there is no way to know in advance whether or not women will be able to use these resources effectively in a given case. As a result, the point should not be to map out in advance the particular forms such customary practices or institutions should take, but rather to design incentives, opportunities, and resources that will allow women in these communities to make whatever creative use of cultural resources they can. Examples of useful elements in such an incentive or opportunity structure include: information about a range of possible practices (produced and distributed by the government), support and training for women who are seeking to reconstruct their local practices through NGOs and government agencies, and the ultimate constraint imposed by the court system and the constitution.

My third suggestion is to abandon and reverse the process of codification of customary law. In Liberia, the national legislature has codified some customary law in statutes intended to be applied by the customary legal system. These statutes should be reconsidered and, in many cases, repealed. The practice of codification has the unfortunate effect of freezing customary law as of the moment it was memorialized, and generally in a form approved by traditional leaders without any consideration of dissenting voices within the community. Customary systems should be encouraged to see themselves as living parts of the culture, adapting and growing in response to the changing needs and views of the community. Allowing communities to engage in this process of developing their customary law, through practices that meet the standards outlined above for a dialogue open to challenge, will create opportunities for women to participate in the interpretation and growth of customary law.

There are a number of ways that this model of dialogue could be implemented legally. First, as I have suggested, it could be made a condition for the granting of recognition for a customary law or an accommodation for a customary practice by a court in a case where a

50. See MORAN, supra note 49 , at $46-50$ (describing this and other incidents).

51. See Becker, supra note 31 , at 31 (arguing for the role of local agency along with external forces). 
cultural community requests such recognition or accommodation. This approach is the simplest in terms of existing legal mechanisms and has the advantage of putting the ball in the community's court, as it were: the process is activated by the community and for its own reasons. In addition, there are mechanisms that might allow a more proactive approach in which the state would require a community to develop such an open dialogic process, independent of any request by the community for accommodation. The Protocol to the African Charter on the Rights of Women in Africa includes a novel and important provision assuring women the right "to participate at all levels in the determination of cultural policies." 52 Similarly, some countries, such as Namibia, have adopted constitutional or statutory provisions that guarantee women some representation or participation in customary systems. ${ }^{53}$ These options are not available in Liberia, which has not signed the Protocol and does not have such a statute, but they open up important possibilities in other contexts.

\section{CONCLUSION}

Let me use the Liberian example to make one final point. I understand that there is a great risk in turning to internal community dialogue to deal with this problem. The cultural evolution that this model hopes to encourage is often a very slow process, and, in the meantime, the women in these communities will be harmed by the persistent gender inequalities enforced by customary law. I do not wish to minimize the costs that women will bear during the time it will take for them to gradually change their cultures. There is a reason, however, why I think that accepting these costs is often the best path to a future of greater equality.

Even if the state could enforce gender equality in a particular casewhich it often is not able to do-in the long run, the welfare of the women in these communities depends on their ability to participate effectively in the shaping of their own culture. If women are dependent on the legal system to step in and redress inequality, then they will be disadvantaged forever. Such state intervention is all too likely to cause a backlash against any women who dare to challenge traditional leaders

52. Protocol to the African Charter on Human and Peoples' Rights on the Rights of Women in Africa, art. 17(1), adopted July 11, 2003, available at http://www.africaunion.org/root/au/Documents/Treaties/Text/Protocol on the Rights of Women.pdf; see Bond, supra note 5, at 522-23 (arguing that this procedural right provides an important mechanism for assuring women's participation in customary systems).

53. Becker, supra note 31 , at 32 (explaining that the Traditional Authorities Act of 1995 "requires traditional authorities to promote women to positions of leadership"). 
or practices. The only way to make stable progress toward equality is for the cultural community to move towards this future through mechanisms it understands to be its own. As a result, one of the most useful things the legal system can do is to create incentives for these communities to adopt such mechanisms. This is why, in the long run, simply protecting individual rights in individual cases is insufficient to achieve equality. Inequality is a structural problem and it requires structural solutions, not just human rights. Equality will only be secured once we have opened the channels for women to make internal change within their own communities. Tying recognition and accommodation to the development of a community dialogue in which challenge is a realistic possibility is one useful way to begin this process. 
